\title{
ALBEDO AND DEGREE OF PUDDLING OF A MELTING COVER OF SEA ICE
}

\author{
By M. P. Langleben
}

(Ice Research Project, Department of Physics, McGill University, Montreal, Quebec, Canada)

\begin{abstract}
Continuous measurements of incident and reflected short-wave radiation have been obtained from 12 May to 17 June 1968 on the ice cover at Tanquary Fiord, Ellesmere Island (lat. $8 \mathrm{I}^{\circ} 25^{\prime} \mathrm{N}$., long. $76^{\circ} 50^{\prime} \mathrm{W}$.). The observations were made with radiometers suspended between two towers at a height of $50 \mathrm{ft}(15 \mathrm{~m})$ to sample an area large enough to be representative of the surface of the ice cover. From the start of surface melting, time-lapse photographs were taken at intervals of $3 \mathrm{~h}$ with a camera mounted on one of the towers at a height of $20 \mathrm{ft}(6 \mathrm{~m})$ and slanted below the horizontal.

Values are presented, for the observation period, of incident short-wave radiation, albedo, air temperature at screen height and percentage of surface covered with melt pools. It is shown that the albedo decreases linearly with increasing area of water puddles.
\end{abstract}

RÉsumé. L'albedo et la quantité des mares d'eau sur la couche fondante de la glace de mer. Des mesures de radiation d'onde courte d'incidence et de réflection ont été obtenues du 12 mai au i 7 juin ig68 sur la couche de glace à Tanquary Fiord, Ellesmere Island $\left(8 \mathrm{I}^{\circ} 25^{\prime} \mathrm{N}, 76^{\circ} 50^{\prime} \mathrm{W}\right)$. Les observations ont été faites avec radiomètres suspendus entre deux tours à une hauteur de $15 \mathrm{~m}$, observont ainsi une surface assez grande pour être représentative de la surface de la glace. Lorsque la surface glacée se mit à fondre, des photographies à intervales de 3 heures furent prises au moyen d'une camera instalée sur l'une des tours à une hauteur de $6 \mathrm{~m}$ et inclinée au dessous de l'horizontale.

Pour cette période d'observation, des valeurs de radiation d'incidence, d'albedo, de temperature de l'air, et du pourcentage de la surface couverte de mares d'eau sont présentees. Il est démontrée que l'albedo décroît linéairement avec la surface croissante des mares d'eau.

Zusammenfassung. Albedo und Wasserbedeckung einer schmelzenden Meereisdecke. Fortlaufende Messungen der einfallenden und reflektierten kurzwelligen Strahlung wurden vom 12. Mai bis zum 17. Juni ig68 auf der Eisdecke des Tanquary Fiord, Ellesmere Island (Breite $81^{\circ} 25^{\prime} \mathrm{N}$, Länge $75^{\circ} 50^{\prime} \mathrm{W}$ ) durchgeführt. Die Beobachtungen wurden mit Strahlungsmessgeräten vorgenommen, die zwischen zwei $15 \mathrm{~m}$ hohen Türmen aufgehängt waren und daher Werte über ein für die Oberfläche der Eisdecke repräsentatives Gebiet ergaben. Vom Beginn der Oberflächenschmelze an wurde der zeitliche Ablauf in 3 Stunden-Intervallen mit Photographien aus einer Kamera verfolgt, die auf einem der Türme in $6 \mathrm{~m}$ Höhe montiert und unter die Horizontale geneigt war.

Für die Beobachtungsperiode werden folgende Werte vorgelegt: einfallende kurzwellige Strahlung, Albedo, Lufttemperatur in Instrumentenhöhe und prozentualer Anteil der von Schmelzlöchern bedeckten Oberfläche. Es wird gezeigt, dass die Albedo linear mit der Zunahme der Fläche der Wassertümpel abnimmt.

\section{INTRODUCTION}

There has been considerable speculation in recent years (Zubov, I948; Wexler, I958; Fletcher, 1965; Donn and Shaw, 1966) about the climatic consequences of a warming trend in the Arctic over the last fifty years or so which, it is believed, is associated with a slight decrease in the ice cover of the Arctic Basin, and under what circumstances this would lead to an ice-free Arctic Ocean. A realistic study of the problem requires an examination of the various terms in the heat-balance equation for this area on a seasonal basis (e.g. Vowinckel and Orvig, 1966, and other papers by these authors). At the moment, there is considerable uncertainty about the fraction of the incoming solar radiation that is absorbed at the surface in the Arctic summer. During this period, insolation is received at the surface continuously; an influx of $800 \mathrm{cal} \mathrm{cm}^{-2} \mathrm{~d}^{-1}\left(388 \mathrm{~W} \mathrm{~m}^{-2}\right)$ is not uncommon in May or June (Langleben, I966) and it is not surprising to find that the fluxes of latent and sensible heat are negligible compared with the radiative flux. The nature of the surface of the ice cover changes rapidly with the disappearance of the snow cover and with the formation of melt pools, and it is therefore of interest to make detailed measurements of temporal changes of albedo of the ice cover.

Time sequences of such observational data are scarce. Values of albedo of an ice cover during the summer have been reported by Marshunova (I96I), Chernigovsky (I963) and Langleben (1966). There is an appreciable spread of values in these measurements, with little 
or no indication of the state of the surface, so that there is insufficient information to resolve the differences. Obviously the choice of site is the determining factor if the measurements are made from a height of about $2 \mathrm{~m}$, which is typical in heat-budget studies.

There is considerable advantage to making albedo measurements from greater heights. Such measurements can be made from aircraft (McFadden and Ragotzkie, 1967, over central Canada), flying the same track day after day if changes in albedo are to be observed. An alternate approach has been used by the author (Langleben, I968) who suspended two radiometers at a height of $50 \mathrm{ft}\left(\mathrm{I}_{5} \mathrm{~m}\right)$ between two towers which were $100 \mathrm{ft}(3 \mathrm{I} \mathrm{m})$ apart. From that height, the response of the downward-viewing radiometer was almost entirely from a circular patch of radius $150 \mathrm{ft}(46 \mathrm{~m})$, an area containing tens of pools and hummocks and hence large enough to be representative of the surface. The work reported here is an extension of the previous investigation. The measurements were carried out at Tanquary Fiord, Ellesmere Island (lat. $81^{\circ} 25^{\prime}$ N., long. $76^{\circ} 50^{\prime} \mathrm{W}$.) from i2 May to i 7 June 1968 . The same arrangement was used to make the radiation measurements as was described by Langleben ( 1968 ). In addition frequent photographs were taken of the ice cover and it has been possible to relate the albedo values to the extent of pool formation.

\section{Observations And Results}

(a) Solar radiation and albedo. The albedo of the surface may be defined as the ratio of reflected to incident solar radiation. Measurements of incident and reflected solar radiation were made with two Kipp hemispherical radiometers. These were gimbal-mounted and supported at a height of $50 \mathrm{ft}\left(\mathrm{I}_{5} \mathrm{~m}\right)$ above the surface by cables attached to two towers which were $\mathrm{I}$ oo $\mathrm{ft}(3 \mathrm{I} \mathrm{m})$ apart. Both pyranometers were recalibrated after use by the Meteorological Branch of the Department of Transport of Canada and there was no significant change in the calibration constants. Observations were recorded continuously on a time-sharing galvanometric recorder of recycling time $6 \mathrm{~min}$; a sequence starting with a galvanometer zero or shorted input reading, followed in $2 \mathrm{~min}$ by a reading of incident radiation and again in $2 \mathrm{~min}$ by a reading of reflected radiation. Further details of the tower construction and calibration are provided in Langleben (1968). It is to be noted that the observations of incident and reflected radiation are not simultaneous and, since considerable variation in incident radiation may occur during cloudy or overcast conditions in an interval of $2 \mathrm{~min}$, that this will tend to introduce error in the albedo values.

Mean hourly values of the incident radiation are shown as the top curve of Figure I starting on 17 May. (The first five days of the observations have been omitted as uninteresting because the state of the ice cover and the albedo both remained more or less unchanged until 20 May.) It is seen in Figure $\mathrm{I}$ that the diurnal variation in incident flux of radiation is such that the peak value is on the average about $0.75 \mathrm{cal} \mathrm{cm}^{-2} \mathrm{~min}^{-1}\left(5^{25} \mathrm{~W} \mathrm{~m}^{-2}\right)$ and the minimum value about $0.2 \mathrm{cal} \mathrm{cm}^{-2} \mathrm{~min}^{-1}\left(140 \mathrm{~W} \mathrm{~m}^{-2}\right)$. Even though hourly averages have been used, the jaggedness in the radiation curve, caused by varying degree of cloudiness, is evident.

Hourly values of the albedo were calculated, each as the mean of ten ratios of reflected to incident radiation and the root-mean-square deviation was determined. Two albedo curves have been plotted in Figure I, one of albedo plus root-mean-square deviation and the other of albedo minus root-mean-square deviation, to indicate the spread caused by non-simultaneity of the radiation readings. The typical root-mean-square deviation is about 0.03 and is comparable to the $3 \%$ error of the radiometers (Bener, 195I). The temporal variation of albedo will be discussed below in relation to changes in the surface of the ice cover.

(b) Temperature. Air temperature at a height of $5 \mathrm{ft}(\mathrm{I} .5 \mathrm{~m})$ was recorded on a thermograph inside a Stevenson screen located adjacent to one of the towers. Two thermometers inside the screen were read periodically to check the calibration of the thermograph. Tem- 
peratures have been plotted as the bottom curve of Figure I. It is seen that the air temperature remained below $0^{\circ} \mathrm{C}$ until I June with the exception of a brief excursion on 29 May to abovezero temperatures. The transition to above-zero temperatures after I June initiated the melting phase.

(c) State of the ice cover. The ice cover in Tanquary Fiord in 1968 was mainly first-year ice of salinity about 5 parts per thousand by weight and of thickness $2.2 \mathrm{~m}$. Initially the surface was partially covered with hard-packed patches of granular snow of thickness up to ${ }_{1} 5 \mathrm{~cm}$ and impregnated with dust wind-driven from the shore. Each wind storm between 12 May and 20 May redistributed the snow drifts without affecting the proportion of bare ice which
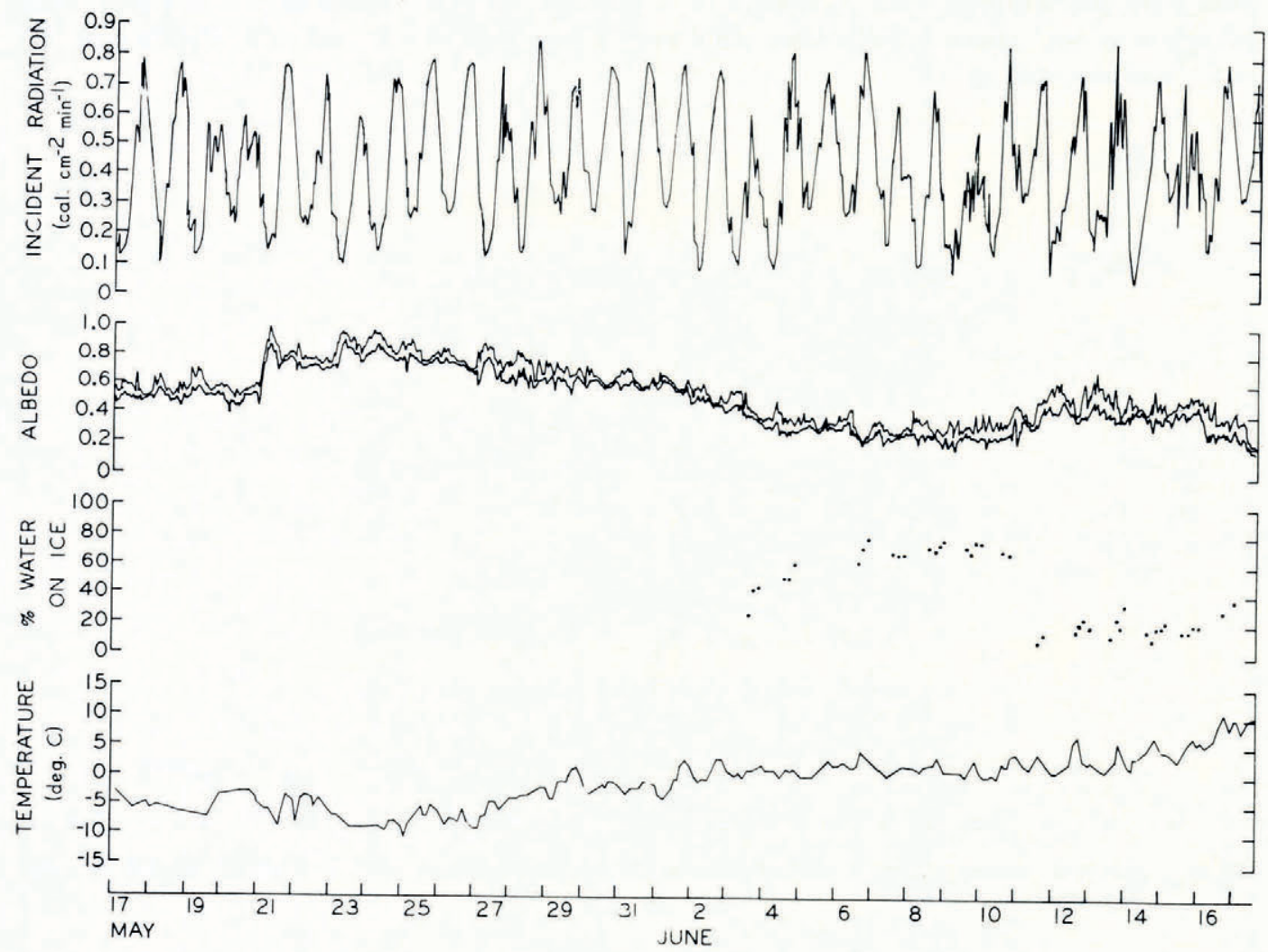

Fig. I (top). Hourly means of incident short-wave radiation at Tanquary Fiord, Ellesmere Island in 1968.

(next to top). Hourly means of albedo of the ice cover. The two curves are of albedo \pm root-mean-square deviation. (next to bottom). Percentage of surface covered by melt pools as a function of time.

(bottom). Air temperature at screen height against time.

remained at about $30 \%$. As was to be expected, the albedo of the surface was relatively constant during this period and so the first five days of observations have not been included in Figure I. A light snowfall on 2 I May temporarily covered the ice cover and was accompanied by an increase of albedo to a value of 0.93 . There were further snowfalls, in trace amount, on 23, 24, 27 and 28 May which again produced peaks in the albedo. Between 29 May and I June the extent of the snow cover rapidly decreased with the air temperature close to $0^{\circ} \mathrm{C}$ and by 2 June, when the temperature rose to $3^{\circ} \mathrm{C}$, surface melt water was first observed. For the remainder of the period of observation, the air temperature was consistently at or above $0^{\circ} \mathrm{C}$ and melt pools, hummocks and drainage channels quickly developed. 
During the melt, a programme of time-lapse photography of the surface was initiated. A remotely triggered camera was mounted on one of the towers at a height of $20 \mathrm{ft}(6 \mathrm{~m})$ with its axis inclined below the horizontal to point towards the base of the other tower. Although the automatically adjusted lens aperture did not function properly, some 43 usable photographs were obtained. The film was projected, frame by frame, and the percentage area of surface covered by melt pools was measured with a planimeter. These 43 values are shown as dots in Figure $\mathrm{I}$ and are seen to be reasonably spaced over the melt period. It is evident by comparing the albedo curve with these values that a large amount of puddling (6-1o June) corresponds to a low albedo value, whereas a lesser degree of puddling (I I-I 5 June) is associated with a higher value of albedo. It is also apparent that during periods when the area occupied by melt pools is increasing, such as $3-4$ June and $16-17$ June, the albedo is at the same time decreasing.

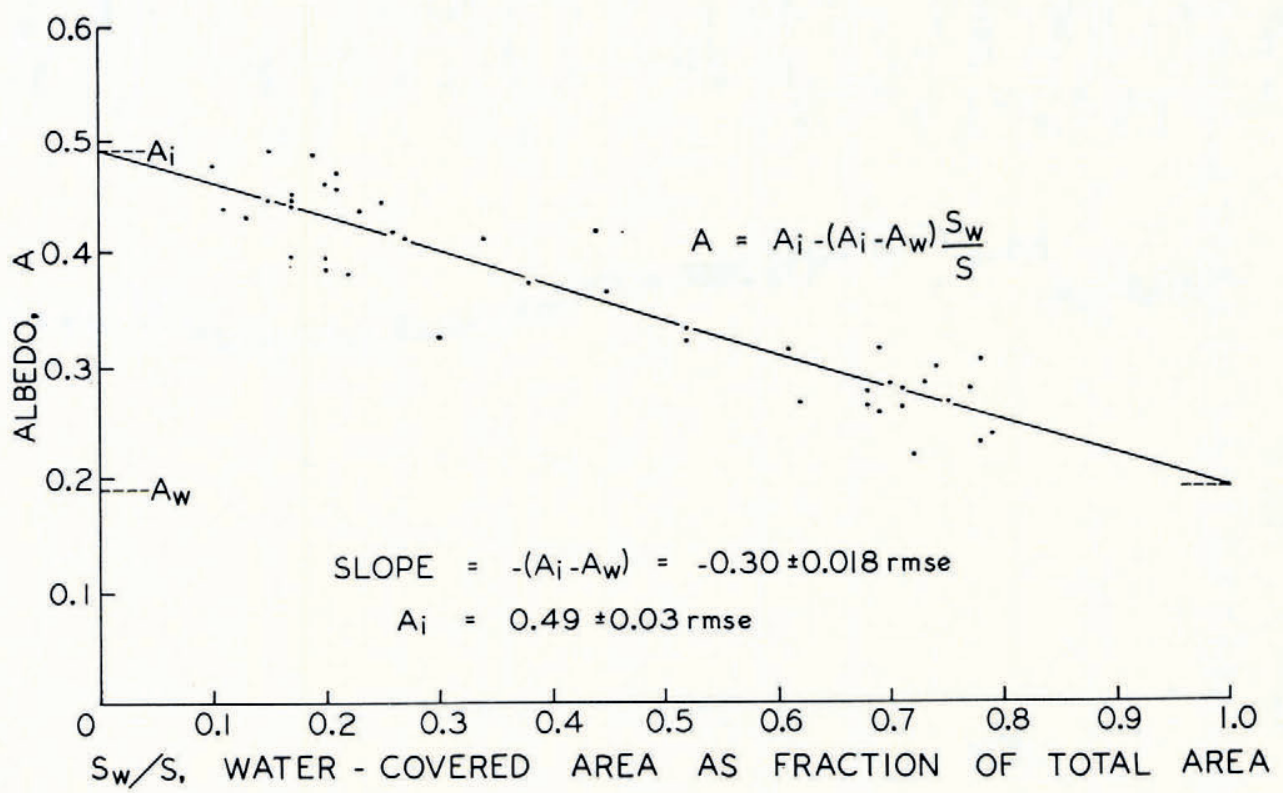

Fig. 2. Albedo of the puddled ice cover A plotted against the fraction of the surface covered by melt pools $S_{\mathrm{w}} / S$. The line shown is a least-squares fit of the data.

(d) Functional relationship between albedo and fractional area of melt pools. It would appear from the observations made in the last paragraph that albedo is related to the fraction of the surface covered by melt pools. Values of albedo coinciding closely in time to the 43 photographs, have therefore been plotted against fractional melt-pool area in Figure 2. In spite of the scatter which is attributed largely to error in measuring off areas on the projected photographs, it is clear that a linear relationship exists between the two variables being considered. The straight line shown is a least-squares fit of slope $-0.30 \pm 0.018$ root-mean-square error. Its intercept on the albedo axis of $0.49 \pm 0.03$ root-mean-square error gives the value of albedo for the ice cover just prior to the development of melt pools.

It is simple enough to demonstrate the theoretical soundness of this linear relationship. Consider some reasonably large representative area $S$ of the surface whose albedo is $A$ containing a random distribution of melt pools. Let $S_{\mathrm{w}}$ and $A_{\mathrm{w}}$ be the area and albedo of the melt pools in the representative area and $S_{\mathrm{i}}$ and $A_{\mathrm{i}}$ the corresponding quantities associated with the ice surrounding the melt pools. 
Now if $I$ is the intensity of radiation incident on the representative area, then the incident flux is $I S$ and the reflected flux is $I A_{\mathrm{i}} S_{\mathrm{i}}+I A_{\mathrm{w}} S_{\mathrm{w}}$.

The albedo of the representative area is

$$
A=\frac{I\left(A_{\mathrm{i}} S_{\mathrm{i}}+A_{\mathrm{w}} S_{\mathrm{w}}\right)}{I S} .
$$

But since $S=S_{\mathrm{i}}+S_{\mathrm{w}}$, we have that

Therefore

$$
A=A_{\mathrm{i}}\left(\mathrm{I}-S_{\mathrm{w}} / S\right)+A_{\mathrm{w}}\left(S_{\mathrm{w}} / S\right) .
$$

$$
A=A_{\mathrm{i}}-\left(A_{\mathrm{i}}-A_{\mathrm{w}}\right) S_{\mathrm{w}} / S
$$

which linearly relates albedo to fractional area of melt pools. The slope and intercepts in Figure 2 have been labelled in terms of this equation. The value of albedo $A_{\mathrm{w}}=0.19$ associated with the melt pools is a reasonable one, although twice as large as the albedo of open water. The melt pools are not very deep and some fraction of the incident radiation would be reflected by the ice at the bottom of the pools.

\section{Discussion}

The albedo of an ice cover during the melt season has been found to be a sensitive function of the extent of water puddles present at the time of measurement. Analysis of the observational data indicated that the albedo decreased linearly with increasing area of puddle formation, and suggested limits in albedo of 0.19 for the melt pools and of 0.49 for the hummocks of ice surrounding the pools. Although the observations were made in an area subject during the winter to surface contamination by dust carried by off-shore winds, it is more than likely that the findings reported here have more general validity. It is true that the initial presence of dust on the surface would tend to hasten the disappearance of the snow cover and the initiation of the melting phase. However the dust soon sinks below the surface and hence would not be expected to influence the albedo of a melting ice cover.

It is much simpler to make broad aerial photographic surveys than measurements of albedo from aircraft where constant attitude is difficult to maintain. It should be possible to combine the results of this paper with aerial photographs to obtain detailed information of space and time variation of albedo in the Arctic Basin.

\section{Acknowledgements}

This work has been supported by the Defence Research Board under D.D.P. Contract GR.8I 3007 and by the National Research Council under Grant No. A-4232. I should like to express my thanks to the Meteorological Branch, Department of Transport for calibrating the radiometers used in this study and to Dr Geoffrey Hattersley-Smith and Mr Harold Serson of D.R.B. for planning the logistics to get men and equipment into the field.

$M S$. received 18 January 1969

\section{REFERENCES}

Bener, P. 195I. Untersuchung über die Wirkungsweise des Solarigraphen Moll-Gorczynski. Beiträge zur Strahlungsmessmethodik III. Archiv für Meteorologie, Geophysik und Bioklimatologie, Ser. B, Bd. 2, Ht. 3, p. 188249 .

Chernigovskiy, N. T. I963. Radiatsionnyye svoystva ledyanogo pokrova tsentral'noy Arktiki [Radiational properties of the central Arctic ice cover]. Trudy Arkticheskogo i Antarkticheskogo Nauchno-Issledovatel'skogo
Instituta, Tom 253, p. 249-60.

Donn, W. L., and Shaw, D. M. of Geophysical Research, Vol. 71, No. 4, p. $1087-93$. 


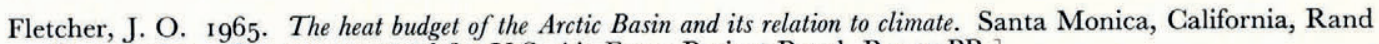
Corporation. [Report prepared for U.S. Air Force Project Rand, R-444-PR.]

Langleben, M. P. I966. On the factors affecting the rate of ablation of sea ice. Canadian Fournal of Earth Sciences, Vol. 3 , No. 4, p. $43 \mathrm{I}-39$.

Langleben, M. P. I968. Albedo measurements of an Arctic ice cover from high towers. Fournal of Glaciology, Vol. 7, No. 5o, p. 289-97.

McFadden, J. D., and Ragotzkie, R. A. 1967. Climatological significance of albedo in central Canada. Fournal of Geophysical Research, Vol. 72, No. 4, p. $1135-43$.

Marshunova, M. S. I96r. Osnovnyye zakonomernosti radiatsionnogo balansa podstilayushchey poverkhnosti i atmosfery v Arktike [Principal characteristics of the radiation balance of the underlying surface and of the atmosphere in the Arctic]. Trudy Arkticheskogo i Antarkticheskogo Nauchno-Issledovatel'skogo Instituta, Tom 229,

p. $5-53$.
Vowinckel, E., and Orvig, S. 1966. Energy balance of the Arctic. V. The heat budget over the Arctic Ocean. Archiv für Meteorologie, Geophysik und Bioklimatologie, Ser. B., Bd. 14, Ht. 3-4, p. 303-25.

Wexler, H. 1958. Modifying weather on a large scale. Science, Vol. 128, No. 3331, p. I059-63.

Zubov, N. N. I948. VI. L'dy arktiki.-VII. Potepleniye arktiki [VI. Arctic ice. VII. The warming of the Arctic]. (In V tsentre arktiki. Ocherki po istorii issledovaniya i fizicheskoy geografii tsentral'noy arktiki [In the centre of the Arctic. Outlines in the history of exploration and the physiography of the central Arctic]. Moscow, Leningrad, Izdatel'stvo Glavsevmorputi, p. 281-373.) [English translation by E. R. Hope: Arctic ice and the warming of the Arctic. ... Ottawa, Defence Research Board, 1950.] 